\title{
Characteristics and drivers of forest cover change in the post-socialist era in Croatia: evidence from a mixed-methods approach
}

Marin Cvitanović 1, George Alan Blackburn 2, Martin Rudbeck Jepsen 3

1. Department of Geography, Faculty of Science, University of Zagreb, Zagreb, Croatia

2. Lancaster Environment Centre, Lancaster University, Lancaster, UK

3. Department of Geosciences and Natural Resource Management, University of Copenhagen, Copenhagen, Denmark

\begin{abstract}
Extensive forests in Croatia represent an important biological and economic resource in Europe. They are characterised by heterogeneity in forest management practices dating back to the socialist planned economy of the pre-1991 era. In this study we investigated the difference in rates of deforestation and reforestation in private- and state-owned forests during the post-socialist period and the causal drivers of change. The selected region of Northern Croatia is characterised by a high percentage of privately owned forests with minimal national monitoring and control. We used a mixed-methods approach which combines remote sensing, statistical modelling and a householdbased questionnaire survey to assess the rates of forest cover change and factors influencing those changes. The results show that predominantly privately owned forests in Northern Croatia have recorded a net forest loss of $1.8 \%$ during the 1991-2011 period, while Croatia overall is characterised by a $10 \%$ forest cover increase in predominantly state-owned forests. Main factors influencing forest cover changes in private forests are slope, altitude, education structure, population age and population density. The results also show that the deforestation in private forests is weakening overall, mostly due to the continuation of the de-agrarisation and deruralisation processes which began during socialism.
\end{abstract}

\section{Keywords}

Post-socialism, Eastern Europe, Forest management, Deforestation, Private forests, Mixed-methods research

\section{Introduction}

In Europe forests cover $37 \%$ of the terrestrial surface and have marked ecological, economical as well as sociocultural significance (Thompson et al. 2009; Fady et al. 2015). Forests play a major role in nutrient retention, air purification, preventing soil erosion, and by sequestering atmospheric carbon they demonstrate great potential for mitigating climate change (Baumann et al. 2012; Xie et al. 2010; Knorn et al. 2012). European forests are distributed unevenly across the continent and are characterised by environmental, historic and economic heterogeneity. Eastern and Central European countries still have large and relatively undisturbed forests compared to Western European countries (Pretzsch et al. 2014; Main-Knorn et al. 2009). However, as a consequence of the demise of socialism, the patterns of forest cover change in Eastern and Central Europe have differed substantially compared to those of Western Europe in the last couple of decades. In Western Europe, nature protection and land abandonment as a result of long-term socioeconomic 
transformation have resulted in an increase in forest cover (Jepsen et al. 2015; Barbati et al. 2014; Gracia et al. 2010), while the changes in forest cover in Eastern and Central Europe show a number of divergent trends.

Research in certain parts of Romania has detected significant forest fragmentation and a sharp increase in forest disturbance rates since 1995 as a result of rapid ownership and institutional changes during the post-socialist era (Kuemmerle et al. 2008; Knorn et al. 2012). In European Russia, changes in forest cover have varied over time with an overall forest increase of $4.5 \%$ from 1990 to 2010, describing a decline in forest cover at the beginning of the post-socialist period and an increase in more recent years, caused partly by forest re-growth on abandoned farmlands (Baumann et al. 2012). A study covering the entire area of the Carpathians shows that forest cover increased continuously from 1985 to 2010 (Griffiths et al. 2014) while the border triangle of Poland, Czech Republic and Slovakia experienced an overall forest loss between 1987 and 2005, but with certain differences among the countries (Main-Knorn et al. 2009).

The variability in forest cover changes among countries and administrative regions in Eastern and Central Europe suggests that differences in political settings, socioeconomic conditions and management practices during and after the socialist era have strongly influenced forest disturbances (Baumann et al. 2012; Prishchepov et al. 2012). The sudden shocks in broad-scale political conditions which occurred in Eastern and Central Europe starting in 1989 have provided a valuable opportunity to study anthropogenic changes of land cover before, after and during the transition between two different political, economic and social systems. The rapid political changes in former socialist countries caused fundamental economic reforms, market liberalisation and the recognition of private property rights. Forest lands were transferred to private ownership through restitution and sale. In some areas of Eastern and Central Europe, this led to increased logging rates by the new private owners, due in part to economic turmoil and crisis as well as weakened institutions which characterised the transition period (Plutzar et al. 2015; Kissling-Näf and Bisang 2001; Kuemmerle et al. 2009).

Diverse patterns of forest transition in Eastern Europe cover a number of micro-trends and land use trajectories, with a distinct difference between the economic system and land tenure rights in the countries of the former Yugoslavia and other former socialist countries. After the Second World War Yugoslavia attempted to develop a unique model of socialism, based on self-management and increased reliance on the market, preserving a certain amount of private ownership (Uvalić 2009). Even though the economic system was based on national five-year development plans, large parts of agriculture and forestry remained privately owned. In 1947, after the law on nationalisation of forest land was passed in the Socialist Republic of Croatia (a former constituent republic of Yugoslavia), around $24 \%$ of forests remained privately owned, but with large regional differences. In some regions the majority of forests remained private because the Law did not apply to small land owners (Anić et al. 2012). Logging was supervised through management programmes and annual plans that were created at the municipality level. Annual logging plans incorporated private forests, but actual logging in private forests exceeded the planned quotas by up to $50 \%$ (Sabadi et al. 1983). The state of private forests depended largely on their accessibility, market conditions, the management decisions of owners and the approach of local administrations. This approach resulted in a wide spectrum of conditions ranging from very well preserved forests to degraded scrublands. 
After the collapse of the socialist regime in 1991, the management of forests in Croatia was transferred to the state-owned company "Hrvatske Šume" (Croatian Forests $L t d$.) and the restitution process begun. Currently, restitution claims are still under way for as many as 300,000 hectares of forest lands (around $13 \%$ of the total forest area). For that reason the private forest sector is considered to represent the most dynamic part of forest management in Croatia, but at the same time it is facing major challenges (Paladinić et al. 2008). The lack of management programmes in private forests has not been easy to solve because the main criterion for inclusion in a management programme is clear ownership of the land, which is a rare occurrence. In particular, during the inheritance process properties have typically acquired multiple ownerships due to equal sharing practices, but these changes have rarely been recorded in land registries (Lovrić et al. 2009). Thus, it is estimated that there are currently around 600,000 forest owners in Croatia, averaging 0.76 ha of forest area per owner. Forest owners are on average over 60 years of age, with little or no formal education and with little interest in cooperation with governmental agencies (Martinić et al. 2006). As a consequence, 30-60\% of private forests in Croatia still do not benefit from any management programmes whatsoever and are practically left to be managed exclusively by their owners (Croatian Ministry of Agriculture 2013). This raises important questions around how the diversity of ownership and large potential heterogeneity in management practices have influenced forests in the postsocialist era. In broad terms, the process of land cover change is influenced by a wide range of political, economic, social and physical geographic factors, which can function on a range of spatial scales (Turner II et al. 1995; Hoshino 1996; Geist et al. 2006; Geoghegan et al. 1998). Accordingly, given the limitations of national-scale centralised forest management programmes in Croatia and increasing private ownership, it is important to consider the variety of factors operating from subnational/regional down to local scales, which may have influenced forest cover change since the demise of socialism.

While the data on changes in forest surface area in Croatia are made available every year on a national level (Croatian Environmental Agency Database 2014), only anecdotal evidence of forest change in specific regions exist, and to the best of our knowledge, there have been no studies in Croatia or any of the former Yugoslav republics that have investigated drivers of any type of land cover dynamics since the fall of socialism. The aim of this project was to estimate forest cover change and understand the drivers of such change. Using Krapina-Zagorje County as a case study, we address this aim through three research objectives:

1. To map forest cover using time series of remotely sensed images and thereby assess the extent, size and distribution of forest cover changes during the post-socialist period;

2. To investigate the relationships between anthropogenic forest cover change and bio-physical and socio-economic factors;

3. To interpret the underlying mechanisms of anthropogenic forest cover change by exploring the decision-making processes related to the forest management and use of forest products at the local/household scale.

\section{The study area}


Forests in Croatia cover around 2,317,000 hectares or $41 \%$ of the entire territory. Although belonging to the Euro-Siberian biogeographic region, continental Croatia is a part of the special Illyrian Floristic Province which encompasses most of South-Eastern Europe (Takhtajan 1986). The region of South-Eastern Europe is considered to have been a major refugee area for temperate deciduous forest species during the Last Glacial Maximum, where many old plant species extinct in Central and Northern Europe survived. They are mostly endemic to this area and contribute significantly to diversity of European flora (Alegro 2000; Manthey et al. 2011).

Regarding forest ownership, currently $81 \%$ of forests in Croatia are state owned and $19 \%$ are privately owned (Croatian Forests Database 2014). Within Croatia, the counties with the highest percentage of privately owned forest are the densely populated counties located north of Zagreb. Among these, Krapina-Zagorje County is the largest and most forested, with forests covering $45 \%$ of its surface, representing $2.5 \%$ of the national forest area. Krapina-Zagorje County has the highest percentage of privately owned forests in Croatia (78\% of its total forest area) which represents $10 \%$ of the national total (Krapina-Zagorje County Spatial Plan 2002). Therefore, this county is an optimal region to study the changes in forest cover during the transition from socialism and the impact of household management on private forests.

Krapina-Zagorje County borders Zagreb to the south, the Republic of Slovenia to the west and Varaždin County to the north and east (Fig. 1). With a population of 133,000 and a surface area of $1224 \mathrm{~km}^{2}$, it is the fourth most densely populated county in Croatia. It is characterised by a hilly undulating landscape, subsistence agriculture and a demographically aged and mostly rural population. The lowest point is the river Krapina at around $110 \mathrm{~m}$ above the sea level, while the highest point is Mt. Ivanščica at $1060 \mathrm{~m}$. Most of the larger settlements are situated in the alluvial plains of the Krapina and Sutla rivers and their hilly surroundings, and most of the mountain slopes are covered with dense forests. Krapina-Zagorje County is characterised by a humid continental climate. The annual precipitation ranges between 850 and $1200 \mathrm{~mm}$, peaking in summer months (Filipčić 2001). Summers are warm with monthly average temperatures in July and August above $20^{\circ} \mathrm{C}$ and monthly averages in January slightly below $0{ }^{\circ} \mathrm{C}$ (CMHS 2014). 

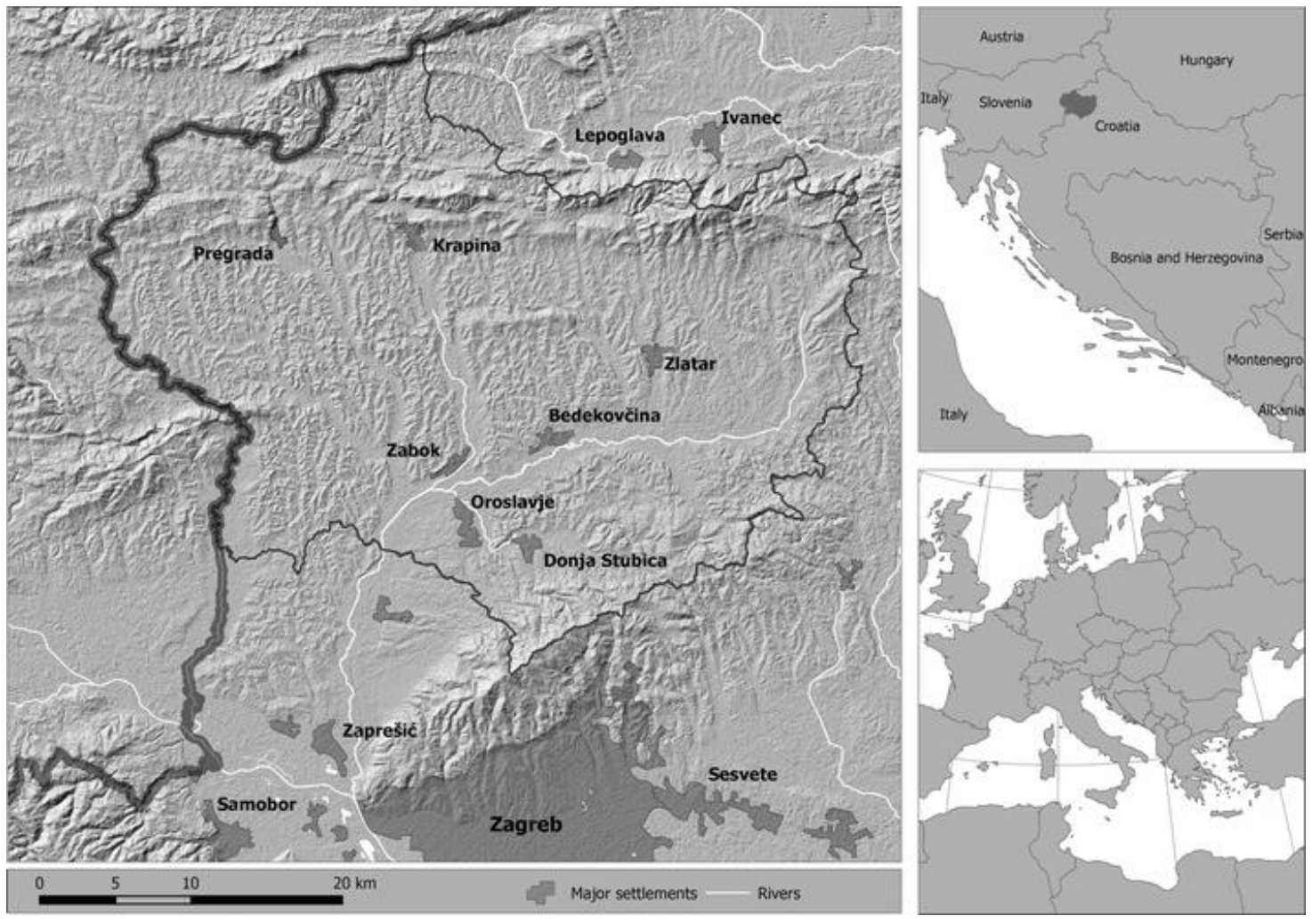

Fig. 1 Study area of the Krapina-Zagorje County

At lower altitudes (up to $400 \mathrm{~m}$ a.s.I.) the forests of Krapina-Zagorje County are dominated by sessile oak (Quercus petraea) and European hornbeam (Carpinus betulus). In comparison with similar Central European forests, these forests are characterised by significantly higher floral diversity and a large number of endemic species, due to this they are called Illyrian oak-hornbeam (ErythronioCarpinion) forests. At altitudes between $400 \mathrm{~m}$ and $800 \mathrm{~m}$, European beech (Fagus sy/vatica) is the most common species of tree, and it mixes with sessile oak, Downy oak (Quercus pubescens) and Hop hornbeam (Ostria carpinofolia). While the typical Luzulo-Fagetum beech forests of this area resemble similar beech forests in Central and Northern Europe (with some differences), a special type of Lamio orvalae-Fagetum beech forests exists in Krapina-Zagorje County, which boasts a large number of endemic species. These forests are floristically the most diverse beech forests in Europe and are endemic to the Western Balkans (Trinajstić 1998; Vukelić 2012).

At the highest altitudes (above $800 \mathrm{~m}$ ) Silver fir (Abies alba), European spruce (Picea albies), Norway maple (Acer plantanoides) and sycamore (Acer pseudoplatanus) can be found along with European beech (Alegro 2000).

Forests in the county develop by way of natural regeneration, rather than by planting (Matic 1999; Croatian Forests Database 2014). Even though the definition of disturbance levels of forests is often ambiguous (Parviainen 1999), forests in Krapina-Zagorje County range from semi-natural to degraded forests, with the main disturbance being cutting down trees as a source of fuel for heating in households. According to a study by Glück et al. (2011), 99 \% of private forests in Croatia are almost exclusively used as a fuel for heating, and for building material. The share of forest owners who sell energy wood on a national level is very low, $<10 \%$ (Halder et al. 2014). Moreover, there is no wood-based industry in Krapina-Zagorje County, and the number of forest-owning households is 
quite high, so this percentage is expected to be even lower in our study region (Krapina-Zagorje County Spatial Plan 2002). The highest parts of the county have been designated as protected areas. In 1978 a Nature Park in the southern part of the region was established, and in 2013 the northern parts of the region were included in the NATURA 2000 programme.

\section{Data and methods}

This research takes a mixed-method approach combining remote sensing with a questionnaire survey and quantitative data modelling. The paper is methodologically divided into three parts. First, the physical changes of the land cover and land use change in Krapina-Zagorje County from 1991 to 2011 were analysed via Landsat satellite images through remote sensing and image classification. Second, the relationships between the observed changes in forest cover and their driving forces were investigated through multiple regression analysis. Regression analysis and other statistical modelling approaches are commonly used in determining the relationships between land cover dynamics and environmental, socio-economic and spatial variables (Peterson et al. 2009). However, the observed changes in forest cover are not sufficient to validate such a model because only correlation without causality can be detected through regression analysis. The omission of human decision-making in such an analysis leads to inconclusive assessment results, which severely limit the potential application of such models (Rounsevell et al. 2012). Therefore, the third part of the study was performed using a detailed questionnaire survey conducted covering 262 households within three administrative units during the second half of 2013. The survey assessed the values, attitudes and behaviour of forest owners (decision-makers) on both individual and household levels. The results received from the questionnaires were used for independent analysis as well as to better interpret the links between drivers of change and the change itself. Private household members are almost exclusively responsible for forest management in the region, which made this type of research possible.

\section{Remote sensing}

Landsat TM and Landsat ETM+ satellite images were used in remote sensing of the Krapina-Zagorje County. The images were downloaded from the Earth Explorer server of the United States Geology Survey (USGS). Images from 29 June, 2011, 2 August, 2000 and 10 September, 1991 had already been geo-referenced, projected, terrain corrected and preselected for their extremely low cloud cover. Images with relatively similar seasonal conditions were chosen to avoid errors due to different phenological phases of vegetation.

The images were classified using a fuzzy $C$ unsupervised classification in TNTmips software and resulting classes were aggregated into "forest" and "other" based on similarities in spectral characteristics and auxiliary data such as ortho-photos and digitised topographic maps from the Croatian State Geodetic Administration Database-CSGAD (2014). Subsequently, the images were filtered with a $3 \times 3$ pixel modal filter to remove noise.

The accuracy of the classification procedure was measured by confusion matrices based on the comparison of classified land cover categories to ground truth data (Richards and Jia 1999). For 2011, land cover information was extracted for 413 random points and compared with land cover data as seen on Google Earth. An additional cross-check was conducted using ortho-photographs of the region from CSGAD. For the 1991 map, the ground truth data were gathered from detailed 
topographic maps of the area at 392 random points. The overall accuracy achieved for the 2011 image was $91.9 \%$ with a 0.93 kappa coefficient, and the overall accuracy achieved for the 1991 image was $83.8 \%$ with a 0.91 kappa coefficient. Apart from the true colour composite and the relatively smaller number of geo-referenced photographs, there were no reference data to calculate the error matrix for the 2000 image. However, the images used for the year 2000 classification are of similar quality to other datasets, the procedure and the software used were the same and the visual interpretation of the classified image gave us reason to conclude that the overall accuracy would not differ much from other datasets.

The final change map was created by combining the forest cover maps from 1991, 2001 and 2011 using the delta comparison procedure. Pixels which changed their value from forest to other were labelled "deforestation", and pixels which changed their value from other to forest were labelled "reforestation", and the total surface of each type was calculated.

Afterwards, the raster data on forest cover change were overlaid with raster-based data on stateowned forests acquired from "Croatian Forests" and processes of forest cover change were calculated separately for both private and state-owned forests. The areas which recorded a change in forest cover belonging to state-owned forests have been excluded from all the analyses.

\section{Regression analysis}

We constructed a regression model to explore the drivers of forest cover change. Data on forest cover change and other variables included in the regression model were aggregated into larger areas (municipalities) where their environmental impact is more visible and more manageable in subsequent modelling (Wood and Skole 1998; Lambin et al. 2003). This level of aggregation was chosen because it represents the most detailed level for which most of our socio-economic and demographic variables were available and because previous research (though limited) has shown that it is the most suitable level for the study of drivers of land use and land cover analysis in Croatia (Cvitanović 2014a; Čuka and Magaš 2003). It is based on settlement patterns and links between households and their associated land plots. There were 32 observations (municipalities) in total. Since the municipalities are widely different in absolute scale, the variables used in regression modelling were standardised. Because both independent and dependent variables demonstrate slow but constant linear trends in the entire studied period, the multiple regression model was based on the data from the first and the last years of the studied period.

The identification of explanatory variables was based on the literature and expert knowledge of the area (Agnoletti 2007; Geist and Lambin 2002; Kristensen et al. 2001). A number of socio-economic variables were available from the 1991 and 2011 Census data (Croatian Bureau of Statistics, 2014). Multicollinearity was checked by excluding variables if its pair-wise correlation with another variable exceeded 0.8. The socio-economic and demographic variables were population density (calculated as a ratio of population to surface area), population ageing (ratio of people aged $>65$ to those aged $<19$ ), higher education structure (proportion of people with higher education in the total population aged $>15$ ) and employment (proportion of employed people in the total population aged $>15$ ).

Regarding geo-physical variables, altitude and slope were chosen as they are the most common predictors of changes in land cover (Monteiro et al. 2011; Teixeira et al. 2014; Geri et al. 2010). They were calculated via ArcGis9.3 and based on digital elevation data from the Advanced Spaceborne 
Thermal Emission and Reflection Radiometer (ASTER GDEM). The altitude variable was divided into altitude categories as follows: 100-200, 200-300, 300-400 m and over $400 \mathrm{~m}$ and then expressed as a share of total territory for each municipality. These categories represent the main landscape features of the region-areas up to an altitude of $200 \mathrm{~m}$ are river valleys where the major cities of the region are found; the areas between 200 and $300 \mathrm{~m}$ are the hilly, densely populated agricultural parts of the region; mountain slopes on the edges of forests are found in the 300-400 m category; and the category over $400 \mathrm{~m}$ represents the highest mountains in the region. Land cover over $400 \mathrm{~m}$ is very homogenous, as forests make up almost all of the land cover, rendering a more detailed categorisation of higher altitudes unnecessary. The second physical geographic variable is slope, divided into several categories: $0^{\circ}-5^{\circ}, 5^{\circ}-12^{\circ}, 12^{\circ}-24^{\circ}$, and $>24^{\circ}$ and expressed as a percentage of total territory for each municipality. The same landscape-based categorisation used for altitude was applied here.

Subsequently, the variables were plotted to a scatter diagram to investigate the linearity of the relationship between the dependent (forest cover change) and the independent variables. The variables were tested for normality by the Shapiro-Wilk test as well as for homoscedasticity using SPSS 20 software, and entered into a multiple regression analysis. Twelve variables in total were included in the initial model, eight representing the slope and altitude categories and four representing socio-economic and demographic characteristics. In order to check the links between the dependent and the independent variables and to reduce the number of variables, backward stepwise regression was used. The final model consisted only of those variables whose exclusion would statistically significantly decrease the explanatory power of the model. In the cases of both deforestation and reforestation, the model reduced the initial 12 variables to four. In total, the statistical modelling accounted for $65.2 \%$ of the observed changes in deforestation and for $64.3 \%$ in reforestation.

\section{Questionnaire survey}

The modelling effort established a correlation between forest cover change and the explanatory variables. We supplemented this with information obtained through a questionnaire survey of a systematic random sample of 262 households in three randomly selected municipalities. The questionnaire consisted of an observational part and a Likert-based scale where values, ideas and opinions about land use and land cover were investigated. This type of survey additionally enabled us to better interpret the links between the drivers of change and the change itself. The study included not only changes in forest cover, but other types of cover, as well as livelihood strategies. Every second household was selected for inclusion in the sample. The person in the household making decisions in relation to agriculture, forest management and household livelihood strategies was guided through a questionnaire consisting of 60 questions.

The respondents were asked 46 questions about their socio-economic status, livelihood strategies, the area and the type of land in their possession, distance from the household to the land, land use, etc. The first part of the questionnaire deals with observed changes in land use/cover and future decisions of respondents regarding their land. The second part deals specifically with forest ownership and management as well as perceived value of forests. The last part consists of 14 Likertbased questions regarding cultural values about land, agriculture, living in the city/village and work. 
The questionnaire was statistically analysed and utilised in the interpretation of the multiple regression modelling (Fig. 2).

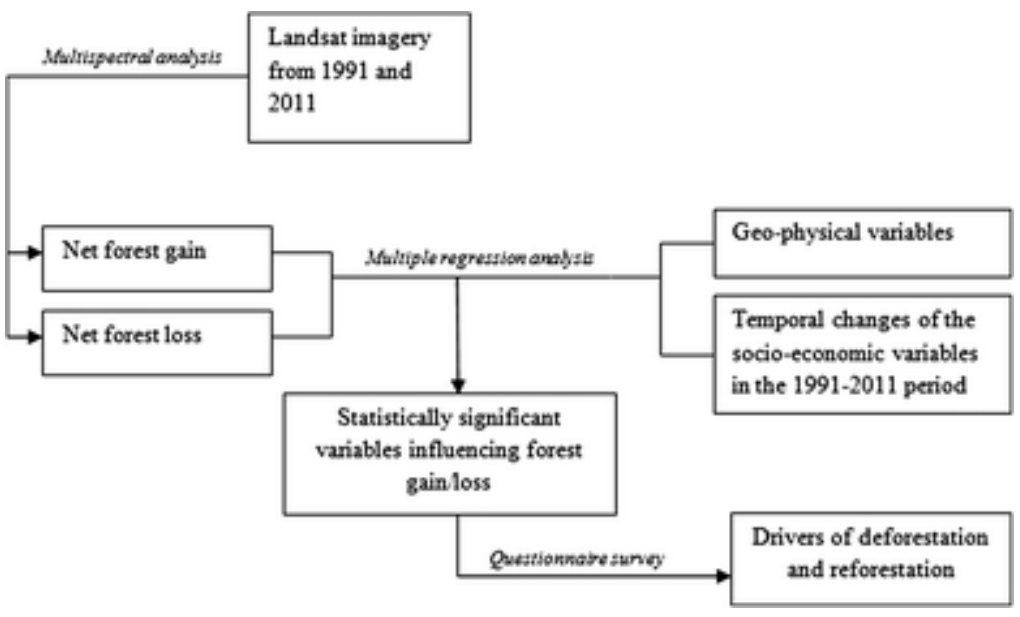

Fig. 2 Structure of research, data and methodology

\section{Results}

\section{Remote sensing}

The unsupervised fuzzy C classification of the Landsat TM and ETM+ showed an overall decrease of $1.8 \%$ in the private forest area in the county. This contradicts the general trends in Croatian forests which show an overall increase of $10 \%$ in the 1990-2010 period (Voća 2012). In total, the overall net forest cover change in private forests is 1000 ha, with 4200 ha (7.5\%) of deforested land and 3200 hectares (5.7\%) of forest re-growth. In the first sub-period, from 1991 to 2001 , the process of forest loss was stronger, resulting in an overall decrease of forest cover of $1.2 \%$. In the second sub-period, from 2001 to 2011, the overall forest cover decreased by $0.6 \%$.

Around $85 \%$ of the forest cover remained intact in the studied period, mostly at altitudes higher than $400 \mathrm{~m}$ where forests cover $93 \%$ of the total surface. At lower altitudes, an overall forest loss was recorded for all of the altitude categories, with the highest deforestation occurring in the 300to 400-m category. An overall forest loss has been recorded on almost all of the slopes $>5^{\circ}$ as well. Only the flat alluvial plains of the county's major rivers (slope $0^{\circ}-5^{\circ}$ ) and the steepest slopes $\left(>24^{\circ}\right.$ ) recorded a slight increase in forest cover (Figs. 3, 4). 


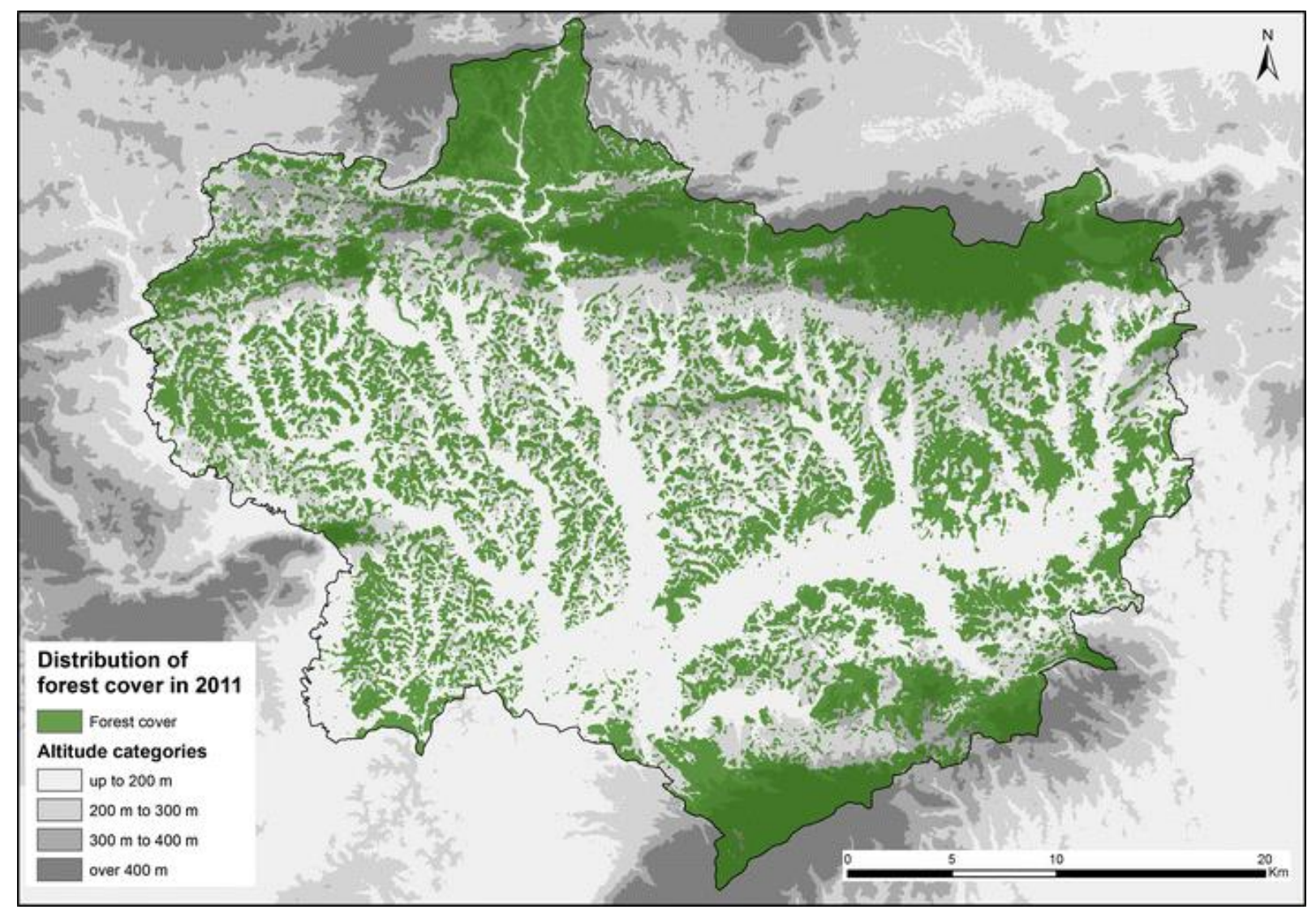

Fig. 3 Distribution of forests in the Krapina-Zagorje County in 2011

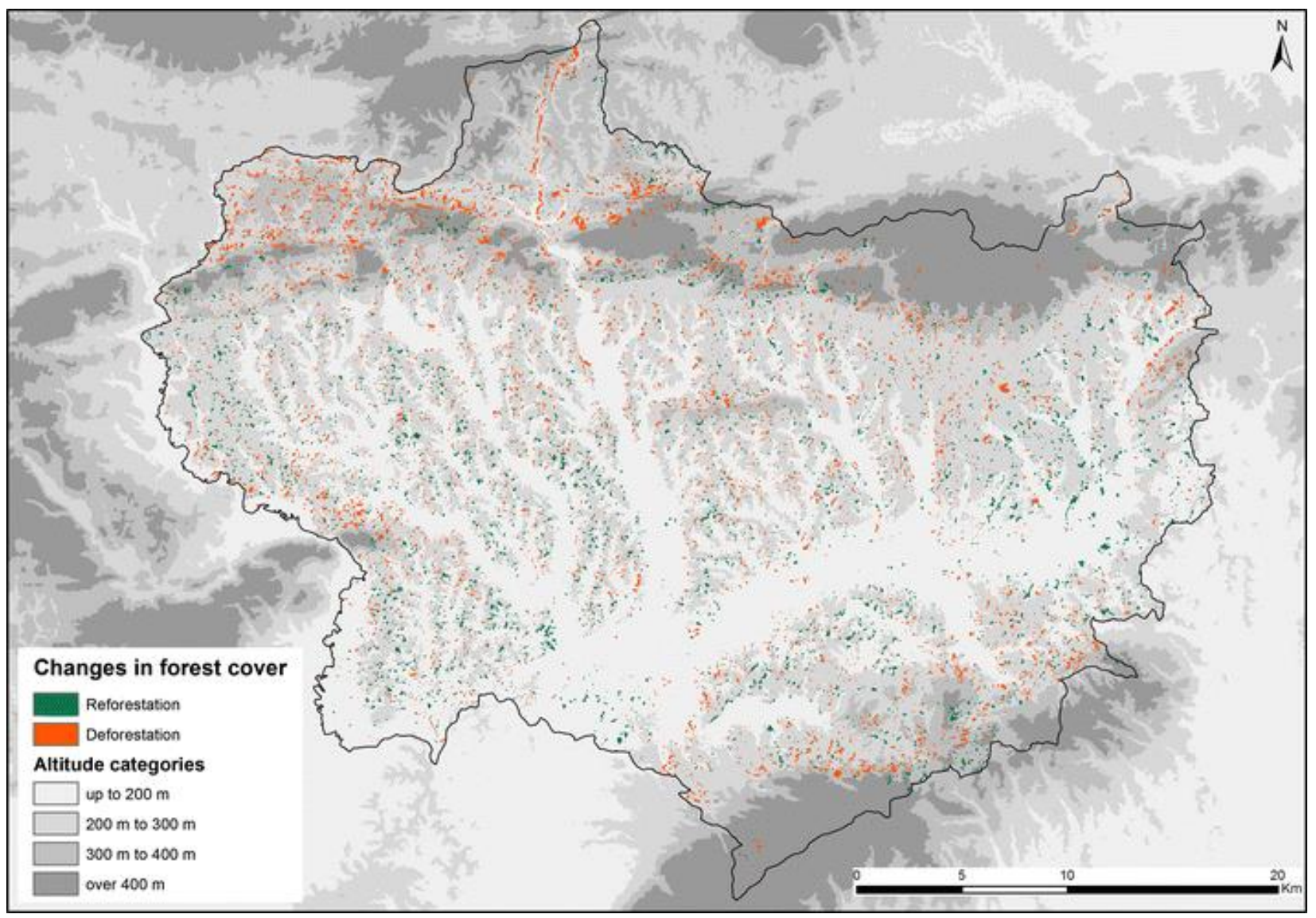


Fig. 4 Changes in forest cover of the Krapina-Zagorje County in the 1991-2011 period

\section{Multiple regression modelling}

The backward stepwise multiple regression modelling reduced the initial 12 variables from 1991 and 2011 Census to six statistically significant variables influencing changes in forest cover. In the case of reforestation, they are population density (negative correlation), altitudes between $300 \mathrm{~m}$ and $400 \mathrm{~m}$ a.s.l. (negative correlation), slopes between $0^{\circ}$ and $5^{\circ}$ (positive correlation), and slopes between $12^{\circ}$ and $24^{\circ}$ (positive correlation). In the case of deforestation, they are population ageing (negative correlation), higher education structure (negative correlation), slopes between $12^{\circ}$ and $24^{\circ}$ (positive correlation), and altitudes between $300 \mathrm{~m}$ and $400 \mathrm{~m}$ a.s.l. (positive correlation).

Regarding forest cover change in the county, the results acquired from the multiple regression modelling show that the altitudes between 300 and $400 \mathrm{~m}$ are experiencing statistically significant rates of forest loss, which were confirmed by the remote sensing results. On the other hand, reforestation is occurring in flat areas $\left(0^{\circ}-5^{\circ}\right)$, which was also confirmed by the remote sensing results. Both increase and decrease in forest cover were observed on $12^{\circ}-24^{\circ}$ slopes, with the direction of change depending on other variables in the model.

In case of socio-economic variables, deforestation is negatively correlated with population ageing and an increase in education levels, meaning that areas which are characterised by higher rates of population ageing and higher education levels are less likely to be deforested. On the other hand, reforestation is consistent with areas showing decreasing population density, i.e. the process of forest re-growth is more likely to occur in areas with an overall population loss (Table 1).

Table 1 Multiple regression coefficients for reforestation and deforestation

\begin{tabular}{lllll}
\multicolumn{5}{c}{ Unstandardised coefficient Standardised coefficient } \\
Independent variable & B & SE & Beta & T \\
Reforestation & & & & \\
Population density & -6.317 & 2.249 & $-0.392^{*}$ & -2.809 \\
Altitudes from 300 to $400 \mathrm{~m}-0.049$ & 0.011 & $-0.595^{* *}$ & -4.687 \\
Slopes $0^{\circ}-5^{\circ}$ & 0.543 & 0.213 & $0.608^{*}$ & 2.553 \\
Slopes $12^{\circ}-24^{\circ}$ & 0.226 & 0.072 & $0.870^{* *}$ & 3.671 \\
Deforestation & & & & \\
Slopes $12^{\circ}-24^{\circ}$ & 0.382 & 0.098 & $0.691^{* *}$ & 3.915 \\
Altitudes 300-400 m & 0.109 & 0.022 & $0.731^{* *}$ & 5.083 \\
Population ageing & -0.073 & 0.020 & $-0.569^{* *}$ & -3.711
\end{tabular}




\section{Unstandardised coefficient Standardised coefficient}

Independent variable

B

Education

$-0.676$

0.223

$-0.485^{*}$

$-2.906$

* Correlation is significant at the 0.05 level

** Correlation is significant at the 0.01 level

\section{Questionnaire survey}

The analysis of the questionnaire survey provided further insight into the causes of the observed forest changes. The average age of the respondents was 43 and $41 \%$ were male. The household statistics in this survey corresponded to the 2011 census data.

Out of the 262 households surveyed, $54 \%$ own a forest and $78 \%$ use wood in their household. The wood is almost exclusively used as the primary fuel for home heating (97\%) but around $11 \%$ of households also use it as a building material. Around $85 \%$ of the surveyed households were connected to the national natural gas grid, which is in line with the average value for the county as a whole.

The usage of wood differed significantly between forest owners and those without forests $\left(x^{2}=16.633, d f=1, p<0.01\right)$. Up to $88 \%$ of households which own a forest use wood in their households, mostly for heating. The corresponding number for those without forests was $66 \%$, meaning that owning a forest statistically increases the chances of using wood in the household. There is also a statistically significant difference between households that buy wood and those which source their own wood, where $66.7 \%$ of households with forests use wood from their own forests $\left(\chi^{2}=126.9, d f=2, p<0.01\right.$. The fact that $85 \%$ of the households have access to natural gas and that $75 \%$ use gas as a heating fuel, but at the same time out of the $75 \%$ that use gas, over twothirds additionally use wood testifies to the fact that natural gas has not completely eliminated the pressure on private forests as a source for heating fuel. Only $31 \%$ of households using natural gas have completely abandoned wood as a heating fuel, with the most common answers for the continual use of wood for heating being the prices of natural gas as the push factor and the availability of wood as the pull factor. Only $33 \%$ of the county's households had access to natural gas before 1991, and the rates of deforestation were somewhat higher (7\% in the 1981-1991 period, see Cvitanović 2014b), which leads to the assumption that the greater availability of natural gas in our studied region has led to less pressure on private forests as a source of heating fuel after all.

Regarding other agricultural practices influencing forest cover change, the respondents estimated how much arable land in their possession was actually cultivated, and how much was abandoned and left to overgrow in the last 30 years. Over $20 \%$ of the respondents stated that they have almost completely stopped cultivating their land over the last 30 years, and additional $12 \%$ currently cultivate around half of their land. The main reasons for the reduction in agricultural practices are advancing age $(28.8 \%)$ and changes in socio-economic circumstances $(25 \%)$, namely a decrease the in prices of agricultural products or higher education levels providing jobs in the secondary and 
tertiary sectors. The land which was first abandoned has been described by the respondents as "too far away" (25\%), "inadequate" (14 \%) or "inaccessible" (10 \%).

Additional insight into the agricultural practices, values and beliefs of the respondents was achieved through the part of the questionnaire based on Likert scale. The respondents were asked to estimate their level of agreement with a number of statements regarding agriculture, living in rural areas, and forest management-ranging from 1 (completely disagree) to 5 (completely agree). Statistically significant differences between the level of education of the respondents and the level of agreement with the statements were checked through rank correlations. The results show that there is a correlation between education level $(p<0.05)$ and the statements: "Agricultural land should be cultivated at any cost" ( $r=-0.140)$, "I want to live in the city someday" $(r=0.142)$, "For a good price I would sell my land" ( $r=0.121$ ) and "I am not practicing agriculture anymore because I can buy food in the supermarket" $(r=0.163)$. In short, people with lower levels of education tended to agree more that the land should be cultivated at any cost, and people with higher levels of education agreed more with other three statements - they would prefer to live in the city and they would sell their land for a good price. Also, availability of food in supermarkets is one of the reasons why people with higher level of education tend to work less in agriculture.

Similar results have been recorded regarding the respondents' age and the level of agreement with several statements. The results show that there is a correlation between age $(p<0.01)$ and the statements: "Abandoned land is a disgrace" $(r=-0.178)$, "Agricultural land should be cultivated at any cost" ( $r=-0.307)$, "I want to live in a city someday" ( $r=0.239)$, "For a good price I would sell my land" ( $r=0.139)$ and "For a good price I would sell my forest" $(r=0.151)$. Older respondents tended to agree more with the first two statements. All correlations are low, but statistically significant (Table 2).

Table 2

Results from the Likert-based scale of values and attitudes regarding agriculture and rural life

\section{Statement}

1. The land is inherently very valuable

2. A person owning agricultural land is a rich person

3. The land will never lose its value

4. Abandoned land is a disgrace

5. Agricultural land should be cultivated at any cost

6. Agriculture is the most difficult profession there is

7. I wouldn't want my children to work in agriculture

8. I want to live in a city someday
N M SD

2624.380 .993

2623.121 .436

2623.721 .270

2624.091 .246

2623.661 .323

2623.241 .499

2623.831 .067

2621.781 .193 
14. Because of my 9-to-5-job I don't have enough time to practice agriculture as much as I would like to

\section{Discussion and conclusions}

Our results demonstrated a marked difference between private- and state-owned forests in Croatia. State-owned forests are managed through national management plans and are characterised by a constant increase in total area surface, while the predominantly private forests in Northern Croatia are characterised by slight deforestation. The data on privately owned forests in other parts of Croatia show their wood biomass increment ${ }^{1}$ to be much smaller than that of state-owned forests (Croatian Forest Database 2014).

These differences between state-owned and privately owned forests can be attributed to several factors. Forest owners in Croatia are, on average, over 60 years of age, with little or no formal education and little interest in forest management practices. Poorly managed land registries inherited from the socialist era, as well as the fragmented character of private forests (average size of parcel is less than $1 \mathrm{ha}$ ), make the creation of comprehensive management strategies even more difficult. As a consequence, between 30 and $60 \%$ of private forests still do not have any kind of official management plans and are directly influenced by their owners' choices regarding livelihood strategies, prices of heating fuel on the market and changes in socio-economic structure.

Findings similar to those discussed in this research have been observed in other post-socialist and post-communist countries in Europe. The results from the European COST Action FP 1201, dealing with forest land ownership in Europe, show that the key issue in management of private forests in Serbia, Slovenia, Bosnia and Herzegovina, Slovakia and Poland during and after the restitution process has been the fragmented character of forest land units and disorderly land registries (Živojinović et al. 2015). This is, in part, seen as the reason for the general lack of interest in management of private forests by their owners as well as their general marginalisation in forestry and economy. The average size of forest land units was reported between 0.6 ha (Serbia) and 2.8 ha (Slovakia) which is seen as a detrimental factor in establishing efficient management plans for private forests. Recently passed laws in Slovakia and Slovenia prevent further fragmentation of forest land units under a certain size during the inheritance process or other changes of ownership (Krč et al. 2015; Ambrušová et al. 2015). Overall, the performance of private forests in these countries in terms of wood production, biomass production or overall management is seen as much lower compared to state-owned forests. This is in line with the results of this research. 
A multiple regression analysis established that six variables accounted for around $65 \%$ of the variance in forest cover change. Regarding geo-physical variables, deforestation is consistent with altitudes of 300-400 m, i.e. with slopes of forested mountains in contact zones with human activity, while reforestation is consistent with flat river valleys characterised by the highest percentage of the region's urban population. Regarding socio-economical characteristics, deforestation is negatively correlated with areas characterised by an increase in education levels and by ageing population. On the other hand, reforestation is seen in areas suffering high rates of depopulation.

These findings demonstrate that several different interconnected factors have been influencing changes in the forest cover in the region. The results gathered from the questionnaire survey provided further insight into the observed changes. Mostly older respondents and those with higher levels of education have stopped practicing agriculture, and at the same time areas with demographically ageing population and those with strongly increasing proportions of higher educated people are less likely to be deforested, showing that agricultural abandonment and employment outside of agriculture are indeed drivers of forest cover change. Additionally, areas with decreasing population are characterised by reforestation.

The results of the Likert-based scale of values and attitudes regarding agriculture and rural life also show that older respondents with lower levels of education tend to agree more with the statements that abandonment of agricultural land is a disgrace and that the land should be cultivated at any cost. At the same time the highest share of the population not involved with cultivating the land is in the oldest age categories. The younger and more educated respondents are less interested in agricultural practices because of the availability of food in supermarkets. Furthermore, they would prefer to live in the city and they would sell their land and forest for a good offer.

All of this indicates that the resulting reforestation can be considered the next phase of deagrarisation and de-ruralisation described in earlier research dealing with agricultural abandonment in Croatia during socialism (Vresk 1972; Malić 1983). Abandoned arable land is first converted into grassland, and then, by means of secondary succession, into forests. Such results are in line with the forest transition theory proposed by Mather and Needle (1998) stating that adjustment to land capability by farmers results in afforestation of marginal land, where cultivation had occurred due to the demands of a growing and largely subsistent population. The shift in agricultural production, concentrated on smaller areas of better quality land, has led to significant abandonment and subsequent reforestation of areas where the soil is less fertile. Such changes are facilitated by technological advancements and by the development of traffic infrastructure and market economies which make the localisation and specialisation of production feasible (Mather and Needle 1998). When asked about their strategy on land abandonment, the respondents cited accessibility and remoteness of land as the main determining factors for land abandonment, which highlights the role marginality plays in the land abandonment process.

Regarding deforestation, the results from the questionnaire survey indicate high levels of wood use in households for heating (78 \%) with a statistically significant link between owning a forest and using wood from said forest. Wood is primarily used for heating (in $96 \%$ of cases), despite the widespread introduction of gas as a heating fuel during the 1990s. After the introduction of gas in households, rates of deforestation decreased, but fuel wood use hasn't been abandoned completely. In the context of growing unemployment and general economic uncertainties it is 
difficult to expect a complete elimination of wood as a heating fuel when it can be sourced for free. If the ongoing restitution process in Croatia brings more forests into private hands, the currently insufficient implementation of forest management plans for private forests could potentially lead to forest disturbances. Research in other parts of Croatia has also demonstrated that private owners are not interested in improving their forest management practices and that the cooperation between private forest owners and governmental agencies is at a very low level (Martinić et al. 2006, Vuletić et al. 2009).

In all, the private forests of Northern Croatia demonstrate a decrease in disturbance levels, benefiting reforestation. A general increase in forest cover is, to date, characteristic only at higher altitudes and in the flat alluvial plains of the region. Higher altitude areas are very sparsely populated, inaccessible, and partially under legal protection. The inclusion of the region's highest mountains into different protected areas (in 1978 and 2013) suggest that, in addition to geo-physical characteristics, national and supra-national conservation policies might have played a role in the process of afforestation in those areas (Valožić and Cvitanović 2011). On the other hand, the flat alluvial plains in the region are areas with the highest rates of increase in the proportion of educated population which, combined with the presence of the highest rates of agricultural abandonment, emphasises the role of socio-economic change in the process of reforestation.

The continuation of the existing trends of increasing rates of reforestation and decreasing rates of deforestation could result in an increase in forest cover in the near future in other parts of the region as well. Similar trends have been noted in other post-socialist countries in Europe where increases in forest cover are mostly connected with agricultural abandonment or agricultural specialisation and the consequential reforestation of abandoned agricultural land. Considerable changes in forest cover in certain countries of Eastern Europe (Slovakia, Poland and Hungary) occurred after their accession to EU in 2004, and the implementation of several EU policies (Živojinović et al. 2015). However, it is still too early for such an analysis in Croatia due to its very recent accession into the European Union. What is certain is that reforestation is a dominant trend in forest cover change on the national level; that the process of deforestation is still occurring in private forests but is weakening and is only characterising some areas; and that a variety of geophysical and socio-economic factors play a role in the process of forest cover change.

Footnotes

1 "Croatian Forests" is not recording their data in terms of forest cover area but rather in wood biomass increment.

\section{Acknowledgments}

This paper has been realised within the projects Environmental change and cultural Landscape as a Development Resource (supported by the Ministry of Science, Education and Sport of the Republic of Croatia) and Croruris-A scenario-based approach to discuss planning and development of Croatian rural areas (Project 4513 supported by the Croatian Science Foundation). The author would like to thank Dr. Erica Smithwick and two anonymous reviewers for their valuable comments during the 
reviewing procedure. The authors would also like to thank Dr. Antun Alegro and Karlo Beljan, mag. ing. silv., for their help.

\section{References}

Agnoletti M (2007) The degradation of traditional landscape in a mountain area of Tuscany during the 19th and 20th centuries: implications for biodiversity and sustainable management. For Ecol Manag 249:5-17. doi:10.1016/j.foreco.2007.05.032 CrossRef

Alegro A (2000) Vegetacija Hrvatske. Botanički zavod PMF-a, Sveučilište u Zagrebu, Zagreb

Ambrušová L, Dobšinská Z, Sarvašová Z, Hricová Z, Šálka J (2015) Forest land ownership change in Slovakia. COST Action FP1201 FACESMAP Country Report, European Forest Institute Central-East and South-East European Regional Office, Vienna.

http://facesmap.boku.ac.at/index.php/library2/doc_download/449-fp1201-country-report-slovakia. Accessed 5 Dec 2015

Anić I, Meštrović Š, Matić S (2012) Značajniji događaji iz povijesti šumarstva u Hrvatskoj. Šumarski List 136:169-176

Barbati A, Marchetti M, Chirici G, Corona P (2014) European forest types and forest Europe SFM indicators: tools for monitoring progress on forest biodiversity conservation. For Ecol Manag 321:145-157. doi:10.1016/j.foreco.2013.07.004 CrossRef

Baumann M, Ozdogan M, Kuemmerle T, Wendland KJ, Esipova E, Radeloff VC (2012) Using the Landsat record to detect forest-cover changes during and after the collapse of the Soviet Union in the temperate zone of European Russia. Remote Sens Environ 124:174-184.

doi:10.1016/j.rse.2012.05.001 CrossRef

CMHS Croatian Meteorological and Hydrological Service (2014) Retrieved from http://klima.hr/ocjene_arhiva_e.html on 27th of August 2014

Croatian Bureau of Statistics (2014) Retrieved from www.dzs.hr on 12th of January 2014

Croatian Environmental Agency Database (2014) Retrieved from:

http://www.azo.hr/BazePodataka07 on 17th December 2014

Croatian Forests Database (2014) Retrieved from: http://portal.hrsume.hr/ on 9th of September 2014

Croatian Ministry of Agriculture (2013) Strategija ruralnog razvoja RH 2008.-2013. Retrieved from http://www.mps.hr/default.aspx?id=3652 on 11th of October 2014

Croatian State Geodetic Administration Database (2014) Retrieved from:

http://geoportal.dgu.hr/\#/on 11th of May 2014

Čuka A, Magaš D (2003) Socio-geografska preobrazba otoka Ista. Geoadria 8:67-86

Cvitanović M (2014a) Land-use and land-cover changes in the Krapina-Zagorje County from 1991 to 2011. Hrvatski geografski glasnik 76(1):41-59 
Cvitanović M (2014b) Promjene zemljišnog pokrova i načina korištenja zemljišta u Krapinskozagorskoj županiji od 1978 do 2011. Ph.D. Thesis, University of Zagreb

Fady B, Cottrell J, Ackzell L, Alía R, Muys B, Prada A, González-Martínez SC (2015) Forests and global change: what can genetics contribute to the major forest management and policy challenges of the twenty-first century? Reg Environ Change. doi:10.1007/s10113-015-0843-9

Filipčić A (2001) Razgraničenje Köppenovih klimatskih tipova Cf i Cs u Hrvatskoj. Acta Geogr Croat 35:7-17

Geist HJ, Lambin EF (2002) Proximate causes and underlying driving forces of tropical deforestation. Bioscience 52:143-150. doi:10.1641/0006-3568(2002)052[0143:PCAUDF]2.0.CO;2 CrossRef

Geist H, McConnel W, Lambin EF, Moran E, Alved D, Rudel T (2006) Causes and trajectories of land use/cover change. In: Lambin EF, Geist $\mathrm{H}$ (eds) Land-use and land-cover change. Springer, Berlin, pp 41-70CrossRef

Geoghegan J, Pritchard JRL, Ognkva-Himmelberger Y, Chowdhury RR, Sanderson S, Turner BL II (1998) "Socializing the pixel" and "Pixelizing the social" in land-use and land-cover change. In: Liverman D, Moran EF, Rindfuss RR, Stern PC (eds) People and pixels: linking remote sensing and social science. National Academy Press, Washington, pp 51-69

Geri F, Amici V, Rocchini D (2010) Human activity impact on the heterogeneity of a Mediterranean landscape. Appl Geogr 30(3):370-379. doi:10.1016/j.apgeog.2009.10.006 CrossRef

Glück P, Avdibegović M, Čabaravdić A, Nonić D, Petrović, N, Posavec S, Stojanovska M, Imoćanin S, Krajter S, Lozanovska N, Marić B, Milijić V, Mrkobrada A, Trninić S (2011) Private forest owners in the Western Balkans-ready for the Formation of the Interest Associations. European Forest Institute Research Report 25, European Forest Institute

Gracia M, Meghelli N, Comas L, Retana J (2010) Land-cover changes in and around a National Park in a mountain landscape in the Pyrenees. Reg Environ Change 11:349-358. doi:10.1007/s10113-0100138-0 CrossRef

Griffiths P, Kuemmerle T, Baumann M, Radeloff VC, Abrudan IV, Lieskovsky J, Munteanu C, Ostapowicz K, Hostert P (2014) Forest disturbances, forest recovery, and changes in forest types across the Carpathian ecoregion from 1985 to 2010 based on Landsat image composites. Remote Sens Environ 151:72-88. doi:10.1016/j.rse.2013.04.022 CrossRef

Halder P, Paladinić E, Stevanov M, Orlović S, Hokkanen TJ, Pelkonen P (2014) Energy wood production from private forests - nonindustrial private forest owners' perceptions and attitudes in Croatia and Serbia. Renew Sust Energy Rev 35:515-526. doi:10.1016/j.rser.2014.04.038 CrossRef

Hoshino S (1996) Statistical analysis of land-use change and driving forces in the Kansai District, Japan. IIASA Working Paper WP-96-120:1-40

Jepsen MR, Kuemmerle T, Müller D, Erb K, Verburg PH, Haberl H, Vesterager JP, Andrič M, Antrop M, Austrheim G, Björn I, Bondeau A, Bürgi M, Bryson J, Caspar G, Cassar LF, Conrad E, Chromý P, Daugirdas V, Van Eetvelde V, Elena-Rosselló R, Gimmi U, Izakovicova Z, Jančák V, Jansson U, Kladnik 
D, Kozak J, Konkoly-Gyuró E, Krausmann F, Mander Ü, McDonagh J, Pärn J, Niedertscheider M, Nikodemus O, Ostapowicz K, Pérez-Soba M, Pinto-Correia T, Ribokas G, Rounsevell M, Schistou D, Schmit C, Terkenli TS, Tretvik AM, Trzepacz P, Vadineanu A, Walz A, Zhllima E, Reenberg A (2015) Transitions in European land-management regimes between 1800 and 2010. Land Use Policy 49:5364. doi:10.1016/j.landusepol.2015.07.003 CrossRef

Kissling-Näf I, Bisang K (2001) Rethinking recent changes of forest regimes in Europe through property-rights theory and policy analysis. For Policy Econ 3:99-111. doi:10.1016/S13899341(01)00059-4 CrossRef

Knorn J, Kuemmerle T, Radeloff VC, Szabo A, Mindrescu M, Keeton WS, Abrudan I, Griffiths P, Gancz $V$, Hostert P (2012) Forest restitution and protected area effectiveness in post-socialist Romania. Biol Conserv 146:204-212. doi:10.1016/j.biocon.2011.12.020 CrossRef

Krapina Zagorje County Spatial Plan (2002) Krapina, Croatia: Zavod za prostorno uređenje Krapinskozagorske zupanije. Retrieved from: http://www.prostor-kzz.hr/prostorni-planovi.html on 14th Dec 2014

Krč J, Pezdevšek Malovrh Š, Ficko A, Šinko M, Premrl T, Bogataj N, Udovč A (2015) Forest land ownership change in Slovenia. COST Action FP1201 FACESMAP Country Report, European Forest Institute Central-East and South-East European Regional Office, Vienna.

http://facesmap.boku.ac.at/index.php/library2/doc_download/454-fp1201-country-report-slovenia. Accessed 6 Dec 2015

Kristensen SP, Thenail C, Kristensen L (2001) Farmers' involvement in landscape activities: an analysis of the relationship between farm location, farm characteristics and landscape changes in two study areas in Jutland, Denmark. J Environ Manag 61:301-318. doi:10.1006/jema.2000.0409 CrossRef

Kuemmerle T, Müller D, Griffiths P, Rusu M (2008) Land use change in Southern Romania after the collapse of socialism. Reg Environ Change 9:1-12. doi:10.1007/s10113-008-0050-z CrossRef

Kuemmerle T, Chaskovskyy O, Knorn J, Radeloff VC, Kruhlov I, Keeton WS, Hostert P (2009) Forest cover change and illegal logging in the Ukrainian Carpathians in the transition period from 1988 to 2007. Remote Sens Environ 113:1194-1207. doi:10.1016/j.rse.2009.02.006 CrossRef

Lambin EF, Geist HJ, Lepers E (2003) Dynamics of land-use and land-cover change in tropical regions. Annu Rev Environ Resour 28:205-241. doi:10.1146/annurev.energy.28.050302.105459 CrossRef

Lovrić M, Martinić I, Landekić M, Šporčić M (2009) Upravljanje privatnim šumama u Europi. Nova mehanizacija šumarstva 30:27-35

Main-Knorn M, Hostert P, Kozak J, Kuemmerle T (2009) How pollution legacies and land use histories shape post-communist forest cover trends in the Western Carpathians. For Ecol Manag 258:60-70. doi:10.1016/j.foreco.2009.03.034 CrossRef

Malić A (1983) Regionalne razlike i promjene površina kategorija iskorištavanja poljoprivrednog zemljišta SR Hrvatske. Hrvatski geografski glasnik 45:55-72 
Manthey M, Fridley JD, Peet RK (2011) Niche expansion after competitor extinction? A comparative assessment of habitat generalists and specialists in the tree floras of south-eastern North America and south-eastern Europe. J Biogeogr 38:840-853. doi:10.1111/j.1365-2699.2010.02450.x CrossRef

Martinić I, Dolenec A, Šporčić M (2006) Stajalište stanovništva Hrvatskog zagorja o općem značenju šume i šumarstva. Radovi (Hrvatski šumarski institut) 41:73-82

Mather AS, Needle CL (1998) The forest transition: a theoretical basis. Area 30:117-124.

doi:10.1111/j.1475-4762.1998.tb00055.x CrossRef

Monteiro AT, Fava F, Hiltbrunner E, Della Marianna G, Bocchi S (2011) Assessment of land cover changes and spatial drivers behind loss of permanent meadows in the lowlands of Italian Alps. Landsc Urban Plan 100:287-294. doi:10.1016/j.landurbplan.2010.12.015 CrossRef

Paladinić E, Vuletić D, Posavec S (2008) Pregled stanja privatnog šumoposjeda u Republici Hrvatskoj. Radovi (Hrvatski šumarski institut) 43:45-57

Parviainen J (1999) Strict forest reserves in Europe-efforts to enhance biodiversity and strengthen research related to natural forests in Europe. In: Parviainen J, Little D, Doyle M, O'Sullivan A, Kettunen $M$, Korhonen $M$ (eds) Research in forest reserves and natural forests in European Countries. European Forest Institute, Joensuu, pp 7-33

Peterson LK, Bergen KM, Brown DG, Vashchuk L, Blam Y (2009) Forested land-cover patterns and trends over changing forest management eras in the Siberian Baikal region. For Ecol Manag 257:911-922. doi:10.1016/j.foreco.2008.10.037 CrossRef

Plutzar C, Kroisleitner C, Haberl H, Fetzel T, Bulgheroni C, Beringer T, Hostert P, Kastner T, Kuemmerle T, Lauk C, Levers C, Lindner M, Moser D, Müller D, Niedertscheider M, Paracchini ML, Schaphoff S, Verburg PH, Verkerk PJ, Erb K (2015) Changes in the spatial patterns of human appropriation of net primary production (HANPP) in Europe 1990-2006. Reg Environ Change. doi:10.1007/s10113-015-0820-3

Pretzsch H, Biber P, Schütze G, Bielak K (2014) Changes of forest stand dynamics in Europe. Facts from long-term observational plots and their relevance for forest ecology and management. For Ecol Manag 316:65-77. doi:10.1016/j.foreco.2013.07.050 CrossRef

Prishchepov AV, Radeloff VC, Baumann M, Kuemmerle T, Müller D (2012) Effects of institutional changes on land use: agricultural land abandonment during the transition from state-command to market-driven economies in post-Soviet Eastern Europe. Environ Res Lett 7:1-3. doi:10.1088/17489326/7/2/024021 CrossRef

Richards JA, Jia X (1999) Remote sensing digital image analysis: an introduction. Springer, BerlinCrossRef

Rounsevell MDA, Arneth A, Brown DG, de Noblet-Ducoudré N, Ellis E, Finnigan J, Galvin K, Grigg N, Harman I, Lennox, J., Magliocca N, Parker D, O'Neil B, Verburg P H, Young O (2012) Incorporating human behaviour and decision making processes in land use and climate system models. GLP Report No. 7. GLP-IPO, São José dos Campos 
Sabadi R, Bijelić B, Jakovac H (1983) Gospodarski rezultati poslovanja u šumarstvu i problemi budućeg razvitka. Šumarski List 107:477-488

Takhtajan A (1986) Floristic regions of the world. University of California Press, Oakland

Teixeira Z, Teixeria H, Marques JC (2014) Systematic processes of land use/land cover change to identify relevant driving forces: implications on water quality. Sci Total Environ 470-471:1320-1335. doi:10.1016/j.scitotenv.2013.10.098 CrossRef

Thompson I, Mackey B, McNulty S, Mosseler A (2009) Forest resilience, biodiversity, and climate change. A synthesis of the biodiversity/resilience/stability relationship in forest ecosystems.

Secretariat of the Convention on Biological Diversity, Montreal

Trinajstić I (1998) Fitogeografsko raščlanjenje klimazonalne šumske vegetacije u Hrvatskoj. Šumar List 122:407-421

Turner II BL, Skole D, Sanderson S, Fischer G, Fresco L, Leemans R (1995) Land use and land-cover change science research plan. IGPB Report No. 35 and HDP Report No. 7. 132

Uvalić M (2009) Investment and property rights in Yugoslavia: the long transition to a market economy. Cambridge University Press, Cambridge

Valožić L, Cvitanović M (2011) Mapping the forest change: using landsat imagery in forest transition analysis within the medvednica protected area. Hrvatski geografski glasnik 73(1):245-255

Voća N (2012) Pregled podataka o korištenju zemljišta i promjenama u korištenju zemljišta u Republici Hrvatskoj. Agencija za zaštitu okoliša, Zagreb

Vresk M (1972) Socijalni ugar i drugi oblici napuštanja agrarne aktivnosti kao posljedica emigracije i socijalnog diferenciranja stanovništva. Hrvatski geografski glasnik 33:79-89

Vukelić J (2012) Šumska vegetacije Hrvatske. Šumarski fakultet, Sveučilište u Zagrebu, DZZP, Zagreb Vuletić D, Krajter S, Mrazek M, Ćorić A (2009) Nedrvni šumski proizvodi i usluge-koristimo li ih dovoljno? J For Soc Croatia 133:175-184

Wood CH, Skole DL (1998) Linking satellite, census and survey data to study deforestation in the Brazilian amazon. In: Liverman D, Moran EF, Rindfuss RR, Stern PC (eds) People and pixels: linking remote sensing and social science. National Academy Press, Washington, pp 70-93

Xie G, Li W, Xiao Y, Zhang B, Lu C, An K, Wang J, Xu K, Wang J (2010) Forest ecosystem services and their values in Beijing. Chin Geogr Sci 20:51-58. doi:10.1007/s11769-010-0051-y CrossRef

Živojinović I, Weiss G, Lidestav G, Feliciano D, Hujala T, Dobšinská Z, Lawrence A, Nybakk E, Quiroga S, Schraml U (2015) Forest Land Ownership Change in Europe. COST Action FP1201 FACESMAP Country Reports, Joint Volume. EFICEEC-EFISEE Research Report. University of Natural Resources and Life Sciences, Vienna. http://facesmap.boku.ac.at/index.php/activities/country-reports.

Accessed 4 Dec 2015 